\title{
Ecology of Alopoglossus angulatus and A. atriventris (Squamata, Gymnophthalmidae) in western Amazonia
}

\author{
Laurie J. Vitt ${ }^{1}$, Teresa Cristina S. Ávila-Pires ${ }^{2}$, Maria Cristina Espósito² ${ }^{2}$ Shawn S. \\ Sartorius $^{1,4}$, and Peter A. Zani ${ }^{3}$ \\ 1 Sam Noble Oklahoma Museum of Natural History and Department of Zoology, University of Oklahoma, Norman, \\ Oklahoma 73072, USA. \\ 2 Coordenação de Zoologia, Museu Paraense Emílio Goeldi/ MCT, Caixa Postal 399, 66017-970, Belém, Pará, Brazil. \\ 3 Department of Biology, Lafayette College, Easton, PA 18042, USA. \\ ${ }^{4}$ Present Address: U.S. Fish and Wildlife Service, Ecological Services, Billings Sub-Office, 2900 4th Ave. N., Billings, \\ MT 59101 USA.
}

\begin{abstract}
Ecology of Alopoglossus angulatus and A. atriventris (Squamata, Gymnophthalmidae) in western Amazonia. We studied the ecology of Alopoglossus angulatus and A. atriventris in western Amazonia. Both species are found in leaf litter of lowland tropical forest, but A. angulatus tends to be found near water whereas A. atriventris is found in terra firme forest. Both tend to be active in shade on sunny and cloudy days. Body size of adults differs (A. angulatus larger), but species differences in sizeadjusted morphology are minor. Sexual dimorphism exists in relative head length (males larger) only in A. atriventris. Diets are similar, with roaches, spiders, grasshoppers/crickets, and springtails dominating the diet. Overall, these lizards are similar ecologically even though they occur together at many sites. Leaf litter and shaded forest appear to be requisites for survival at the local level.
\end{abstract}

Keywords: Squamata, Gymnophthalmidae, Alopoglossus, microteiid, lizard ecology, Amazônia.

\section{Introduction}

Lizards in the family Gymnophthalmidae are among the poorest known ecologically in the New World even though more than 160 species are distributed widely through much of South

Received 27 October 2006.

Accepted 11 April 2007.

Distributed June 2007. and Central America (Zug et al. 2001, Pough et al. 2004). Most are small, and most live in leaf litter (e.g., Duellman 1978, 1987, Ávila-Pires 1995, Vitt and de la Torre 1996, Vitt et al. 1998a), but some live along the land-water interface (e.g., Vitt et al. 1998b). Nevertheless, some species are widespread in cerrados (seasonally wet savannas) and caatingas (semiarid regions) where they often occur at high density (Moraes 1993, Vitt 1995, Rodrigues 
1996, Colli et al. 2002). Reduced limbs and body elongation have evolved several times independently, and some species are semiaquatic (Beebe 1945, Hoogmoed 1973, ÁvilaPires 1995, Vitt and Ávila-Pires 1998, Pianka and Vitt 2003). Their evolutionary relationships are just beginning to be understood (Pellegrino et al. 2001, Doan 2003, Castoe et al. 2004, Doan and Castoe 2004, Rodrigues et al. 2005).

We describe in detail the ecology of two rainforest species of Alopoglossus studied in western Amazonia. Alopoglossus angulatus is widespread in most of Amazonia, while $A$. atriventris occurs only in the western part. Both are found in leaf litter and neither has been well studied. Brief summaries of some of the data presented here (e.g., mean SVL, general diet summary) have been used in other analyses (Vitt et al. 2003a, Vitt and Pianka 2005), but thorough data presentation and analyses have not appeared previously. We describe habitat, microhabitat, and the thermal environments used by these lizards, their size, morphology, and sexual dimorphism, and their diets. These data should prove useful for continuing phylogenetic analyses of ecological data and should provide a background for these species in assessing habitats for conservation.

\section{Materials and Methods}

We collected data on a total of $59 A$. angulatus and $22 \mathrm{~A}$. atriventris at five localities in the western Amazon rainforest: (1) northeastern Ecuador in Sucumbíos Province $\left(0^{\circ} 0^{\prime}, 76^{\circ} 10^{\prime} \mathrm{W}\right)$ near the Rio Cuyabeno (hereafter "Cuyabeno") during February - April 1994 (rainy season); (2) approximately $5 \mathrm{~km} \mathrm{~N}$ of Porto Walter, Acre (hereafter "Rio Juruá”), $\left(8^{\circ} 15^{\prime} \mathrm{S}, 72^{\circ} 46^{\prime} \mathrm{W}\right)$ in undisturbed terra firme rainforest of the Juruá River Basin during February-April 1996 (rainy season); (3) the Rio Ituxi in the southwestern portion of Amazonas (hereafter “Rio Ituxi”) (8²0' S, 6543' W) in moderately disturbed rain forest during JanuaryApril 1997 (rainy season); (4) approximately 40

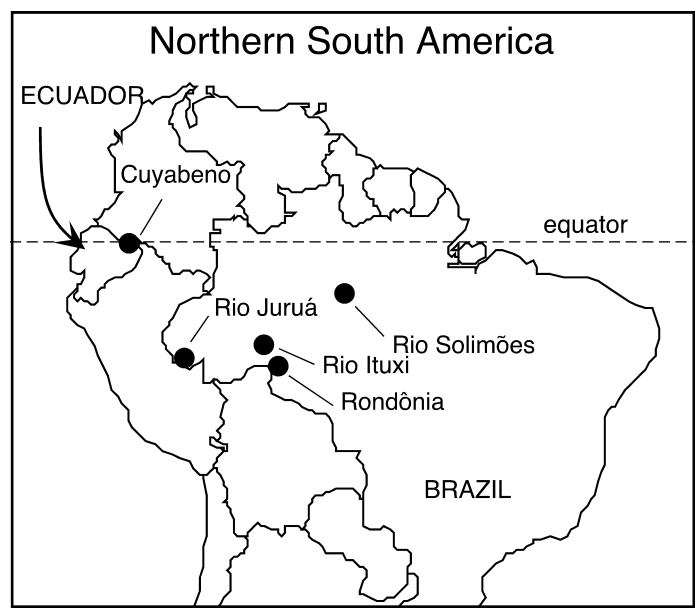

Figure 1 - Map showing localities in which Alopoglossus were studied.

km E of Guajará-Mirim, Rondônia, Brazil (hereafter “Rondônia”) (10¹9' S, 64³4’ W) in tropical lowland forest during January-March 1999 (rainy season); and (5) south of the Amazon River and nearly due south of Manaus, Amazonas (hereafter "Rio Solimões”) (320' S, $59^{\circ} 04^{\prime} \mathrm{W}$ ) in moderately disturbed rainforest during December-January, 1998-1999 (rainy season) (Figure 1).We combined data from all sites to provide this general account of the ecology of these lizards.

For most lizards observed or captured, we recorded habitat type, microhabitat, whether it was sunny or cloudy, exposure of lizards, and time of day. We condensed our original seven microhabitat categories to five: ground, inside folded palm frond, leaf litter, tree trunk, and water. Likewise we condensed our original 18 habitat categories (all localities combined) to five broad categories: stream (linear structure with banks), swamp (includes pond edge), undisturbed terra firme forest, disturbed terra firme forest, and low primary forest (holds water during and after rains-includes wet palm forest). Exposure categories were: shade, filtered sun, and, full sun (full exposure to sky regardless of whether it was sunny or cloudy). 
We were only able to measure cloacal temperatures $\left(\mathrm{T}_{\mathrm{b}}\right)$ for two individual $A$. atriventris. However, we measured substrate (microhabitat) and air temperatures at the exact spot where many lizards were captured. Because of the small size of these lizards (thus low thermal inertia) and the observation that most were in shade or filtered sun (avoiding heat gain), these likely approximate $T_{b}$. We assigned time of day each lizard was observed to hourly categories for analysis and compared species activity periods with a Wilcoxon Signed Rank test.

Following capture, lizards were taken to our field laboratories, euthanized following standard procedures (Anonymous 1987), and the following morphological measurements were taken: snout-vent length (SVL), length of tail base (original portion), and regenerated tail (if any) to $1.0 \mathrm{~mm}$; total body mass to $0.01 \mathrm{~g}$ with Acculab digital field balances; head width (widest point), head length (tip of snout to anterior edge of tympanum), head height (greatest height), body width, body height, foreleg length (body posterior to limb to tip of longest toe), and hindleg length (body anterior to limb to tip of longest toe) to $0.01 \mathrm{~mm}$ with digital calipers. Lizards were then fixed in $10 \%$ formalin and stored in $10 \%$ formalin until they could be moved to $70 \%$ ethanol (usually 3 days to 1 month, depending on locality). To quantify sexual dimorphism (if any), we first compared size (SVL) of lizards $40 \mathrm{~mm}$ SVL and larger (all sexually mature) with a Mann-Whitney U test. We included lizards $\geq 40 \mathrm{~mm}$ to be absolutely certain that no juveniles were included in the analysis. To test for species and sexual differences in size-adjusted morphology, we first $\log _{10}$-transformed all morphological variables. We then performed a MANCOVA with log-SVL as the covariate and species and sex as class variables to determine whether an overall model effect existed. We then used a stepwise discriminate analysis on regression residuals keeping only variables contributing significantly to the model $(\mathrm{P}<0.05)$. Pseudoprobabilities generated by stepwise regression were used to indicate variables that contributed most to the relationship.

Later, stomachs were removed and reproductive organs were examined. Stomach contents were spread on a Petri dish, prey items carefully separated, identified to family level when possible, and measured for length and width. We later grouped prey into 20 broad categories, similar to those used by others (e.g., Pianka and Vitt 2003). We considered ants as a category separate from other hymenopterans because their collective morphotype differs from most others. Because individual prey items were compressed into a bolus approximating the shape of a prolate spheroid, we used the following formula to estimate individual prey volumes:

$$
V=\frac{4}{3} \pi\left(\frac{\text { length }}{2}\right)\left(\frac{\text { width }}{2}\right)^{2}
$$

Alternative methods exist for determining prey sizes and not all methods produce comparable results (Magnusson et al. 2003). We encourage investigators to carefully weigh the benefits of alternative methods when designing diet studies within the context of equipment and time constraints. We used the program BugRun, a $4^{\text {th }}$ Dimension ${ }^{\circledR}$-based analysis to produce dietary summaries, calculate mean prey size (length, width, and volume) for each lizard, estimate total prey volume, and calculate niche breadth using the inverse of Simpson's (1949) diversity measure (Pianka 1973, 1986):

$$
\beta=\frac{1}{\sum_{i=1}^{n} p_{i}^{2}}
$$

where $p$ is the proportional utilization of each prey type $i$ and Niche breadth values $(\beta)$ vary from 1 (exclusive use of a single prey type) to $n$ (equal use of all prey). We $\log _{10}$ - transformed all 
quantitative data to normalize distributions for further analyses.

Linear regression on $\log _{10}$-transformed variables determined whether prey size and number of prey eaten varied with lizard body size. ANCOVAs with $\log _{10}$ SVL as the covariate and sex as the class variable were used to determine whether prey size or number of prey eaten differed between species or sexes. Plots of $\log _{10}$-stomach volume versus $\log _{10}$-SVL determined the relationship between stomach volume and lizard size. Relative fullness of lizards was estimated by totaling volume of all prey for each stomach and regressing these values on SVL. Percentage of lizards with prey in the stomachs was calculated by dividing number of lizards containing prey by the total sample size and multiplying by 100 (Huey et al. 2001).

Most statistical analyses were performed with JMP 6.0 or StatView (both marketed by SAS Inst.). Voucher specimens were deposited in the herpetology collection of the Museu Paraense E. Goeldi (MPEG) in Belém (Brazil), the Museo de Zoología de la Pontificia Universidad Católica (QCAZ) in Quito (Ecuador) and the Sam Noble Oklahoma Museum of Natural History (OMNH) in Norman (USA).

\section{Results}

\section{General ecology}

Both species of Alopoglossus are small, dark colored, and difficult to see until they move when in leaf litter (Figure 2). Most $A$. angulatus were found in habitats associated with water whereas most $A$. atriventris were found in terra firme forest (Figure 3). Nevertheless, differences in habitat use were not significant, although marginal (Wilcoxon signed-rank test, $\mathrm{Z}=-1.83$, $\mathrm{P}=0.068$ ). A vast majority of individuals of both species were first found in leaf litter (Figure 4) and no difference in microhabitat occurrence was detected (Wilcoxon signed-rank test, $\mathrm{Z}=-1.34, \mathrm{P}=0.180)$. No A. angulatus were observed above leaf litter. Only two $A$. atriventris were observed above leaf litter. Both were on the base of tree trunks in the forest, less than $1 \mathrm{~m}$ off ground (both at $0.6 \mathrm{~m}$ ). Trunk diameters were 16 and $40 \mathrm{~cm}$. Thirty-three of 58 (56.9\%) A. angulatus and 14 of 22 (63.6\%) A. atriventris were found on cloudy days, the remainder on sunny days. Of those, 41 (70.7\%) A. angulatus and 13 (59.1\%) A. atriventris were in shade, 22 (27.5\%) A. angulatus and 15 (25.9\%) A. atriventris were in filtered sun, and 2 (3.5\%) A. angulatus and 2 (3.4\%) A. atriventris were in full sun exposure. The two A. angulatus in full sun exposure were active on sunny days but the two A. atriventris in full sun exposure were active on cloudy days. $\mathrm{T}_{\mathrm{b}}$ of two $A$. atriventris for which we had data averaged $26.1^{\circ} \mathrm{C}\left(24.9,27.2^{\circ} \mathrm{C}\right) . \mathrm{T}_{\mathrm{ss}}$ and $\mathrm{T}_{\mathrm{a}}$ for $10 \mathrm{~A}$. angulatus averaged $25.1 \pm 0.3^{\circ} \mathrm{C}\left(22.9-26.6^{\circ} \mathrm{C}\right)$ and $25.9 \pm 0.4^{\circ} \mathrm{C}\left(22.8-28.2^{\circ} \mathrm{C}\right)$, respectively and for 10 A. atriventris, $25.7 \pm 0.4^{\circ} \mathrm{C}(23.5-$ $28.0^{\circ} \mathrm{C}$ ) and $26.6 \pm 0.4^{\circ} \mathrm{C}\left(23.8-29.2^{\circ} \mathrm{C}\right)$, respectively. The small differences in $\mathrm{T}_{\mathrm{ss}}$ and $\mathrm{T}_{\mathrm{a}}$ between species were not significant (ANOVAs, $\mathrm{F}_{1,18}=0.79, \mathrm{P}=0.79$ and $\left.\mathrm{F}_{1,18}=1.24, \mathrm{P}=0.28\right)$.

Individuals of both species were observed active throughout the day with peak activity occurring in mid-day for A. angulatus and late morning for $A$. atriventris (Figure 5). Differences in activity periods were significant (Wilcoxon Signed Rank test, $\mathrm{Z}=-2.37, \mathrm{P}=$ 0.018).

\section{Morphology and sexual dimorphism}

Among adults (SVL $=40 \mathrm{~mm}$ ), Alopoglossus angulatus reach larger overall size (SVL) than A. atriventris (Figure 6) and species differences for both sexes are significant (males, MannWhitney U test, $\mathrm{Z}=-2.49, \mathrm{P}=0.012$; females, Mann-Whitney $\mathrm{U}$ test, $\mathrm{Z}=-2.76, \mathrm{P}=0.006$ ). No detectable sexual size dimorphism exists in adults of $A$. angulatus (Mann-Whitney $\mathrm{U}$ test, $\mathrm{Z}$ $=-1.31, \mathrm{P}=0.189$ ) or $A$. atriventris (MannWhitney U test, $\mathrm{Z}=-0.75, \mathrm{P}=0.455)$. Adult $A$. angulatus averaged $55.4 \pm 1.6 \mathrm{~mm}$ SVL and 


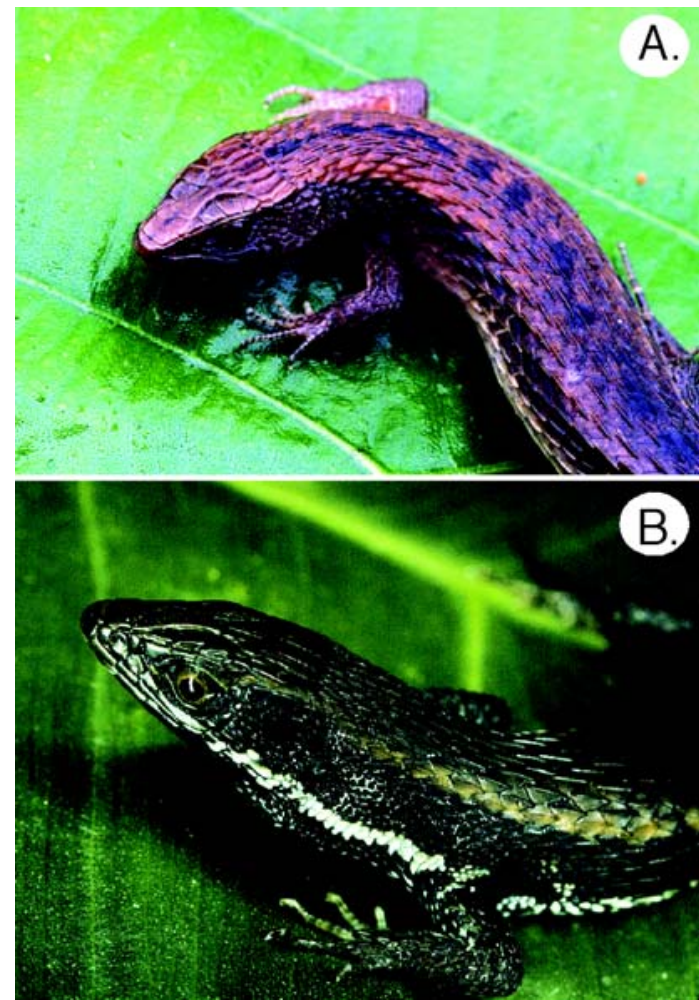

Figure 2 - (A) Female Alopoglossus angulatus from the Rio Formoso, Rôndonia, Brazil collected in 1998 (OMNH 37337). (B) Male Alopoglossus atriventris from Cuyabeno, Ecuador collected in 1994 (OMNH 36439).

weighed $4.09 \pm 0.29 \mathrm{~g}$ and adult $A$. atriventris averaged $44.9 \pm 2.9 \mathrm{~mm} \mathrm{SVL}$ and weighed 2.02 \pm 0.42 g. Our MANCOVA on morphological variables revealed a significant model effect (Wilks' Lambda $=0.008, \mathrm{~F}=54.5, \mathrm{P}<0.001$ ). We then applied the stepwise discriminate analysis on regression residuals to test for species differences in size-adjusted morphological variables. Only one variable, relative head length was retained $(P<0.05)$. Even though species differed in relative head length, 32.5\% (28 of 86) of individuals were misclassified (wrong species) based on relative

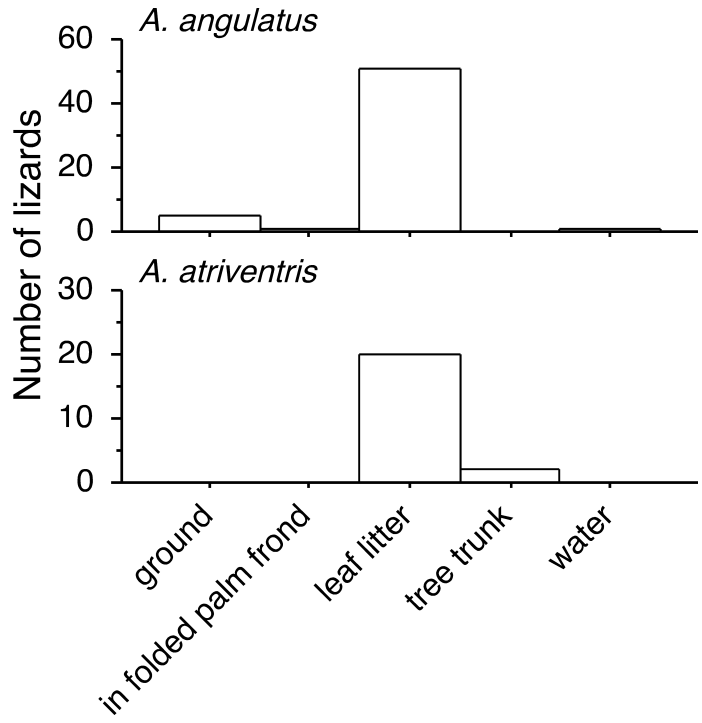

Figure 3 - Habitat use by Alopoglossus angulatus and A. atriventris in western Amazonia.

head length. We conclude that species differences in overall morphology likely have little ecological significance. We then re-ran the MANCOVA on each species separately, calculated residuals restricted to regressions within each species, and applied the stepwise discriminate analysis manually removing nonsignificant morphological variables to examine sexual differences in morphology. For A. angulatus, the model effect of the MANCOVA was significant (Wilks' Lambda = $0.008, \mathrm{~F}=68.1, \mathrm{P}<0.001)$. After stepwise reduction of variables, relative mass and relative tail length remained significant ( $F$ values < 0.043). Nevertheless, 34.7\% (18 of 49) of lizards were misclassified (wrong sex). For $A$. atriventris, the model effect of the MANCOVA was also significant (Wilks' Lambda $=0.005, \mathrm{~F}$ $=66.6, \mathrm{P}<0.001$ ). After stepwise reduction of variables, only relative head length remained significant $(F<0.001)$. Seven of $37(18.9 \%)$ were misclassified. We conclude that even though sexual differences exist in both species, 


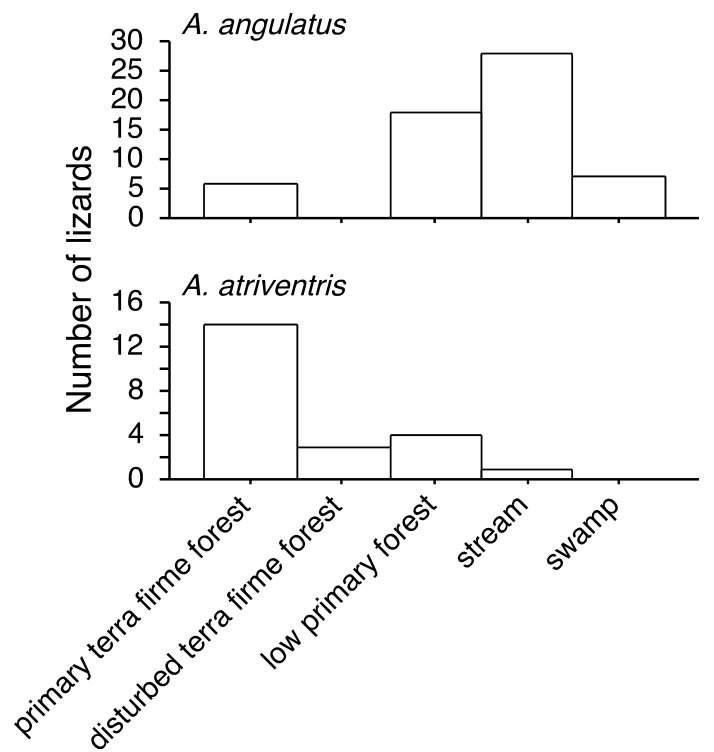

Figure 4 - Microhabitat use by Alopoglossus angulatus and A. atriventris in western Amazonia.

they are not reliable for sexing individuals and sexual dimorphism is not impressive in $A$. angulatus. However, sexual dimorphism in relative head length occurs in $A$. atriventris.

\section{Composition of the diet}

The diet of both Alopoglossus species is dominated volumetrically by a combination of roaches, spiders, and grasshoppers/crickets (Table 1). These three categories account for $92.3 \%$ of the diet of $A$. angulatus and $94.3 \%$ of the diet of $A$. atriventris volmetrically. The primary difference between the two is that $A$. angulatus ate relatively more spiders and $A$. atriventris ate relatively more grasshoppers/ crickets volumetrically. Numerically, spiders, springtails (Collembola), and grasshoppers/ crickets dominate the diets of both species. These four prey categories account for $45.7 \%$ of the diet of $A$. angulatus and $53.6 \%$ of the diet of A. atriventris numerically. Niche breadths were similar for numerical (6.99 and 5.93 for $A$.

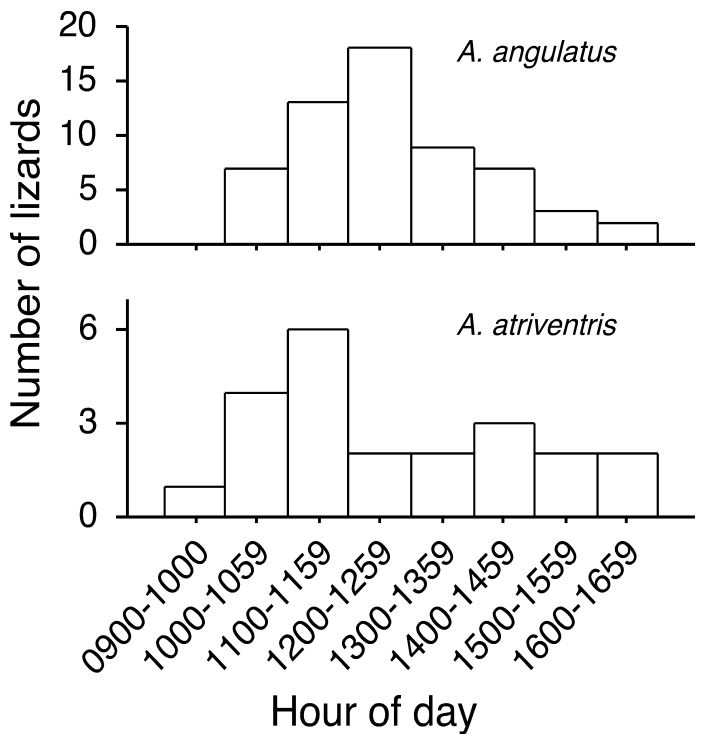

Figure 5 - Number of Alopoglossus angulatus and A. atriventris observed during each hour of the day.

angulatus and $A$. atriventris, respectively) and volumetric (2.55 and 2.47 for A. angulatus and A. atriventris, respectively) data.

One-hundred and seventy-seven prey items from 39 A. angulatus (79.6\% of 49 sampled) averaged $3.55 \pm 0.33(0.2-43.47) \mathrm{mm}$ in length, $1.38 \pm 0.1(0.12-7.7) \mathrm{mm}$ in width, and $18.02 \pm$ 4.13 (0.01-375.32) $\mathrm{mm}^{3}$ in volume. Sixty-nine prey items from 19 A. atriventris $(51.4 \%$ of 37 sampled) averaged $3.92 \pm 0.41$ ( 0 . (79.6\% of 49 sampled) 28-12.27) $\mathrm{mm}$ in length, $1.49 \pm 0.19$ (0.15-7.28) $\mathrm{mm}$ in width, and $22.2 \pm 6.57$ (0.01-326.89) $\mathrm{mm}^{3}$ in volume. Significant relationships existed between $\log _{10}$-transformed measures of prey size (individual means of prey length, width, and volume) and $\log _{10}$-SVL $\left(\mathrm{R}^{2}\right.$ varied from $0.27-0.37$, $\mathrm{P}$ values varied from $<$ 0.0001 to 0.001$), \log _{10}$-number of prey $\left(\mathrm{R}^{2}=\right.$ $\left.0.078, \mathrm{~F}_{1,56}=5.79, \mathrm{P}=0.0194\right), \log _{10}$-total prey volume $\left(\mathrm{R}^{2}=0.239, \mathrm{~F}_{1,56}=18.88, \mathrm{P}=0.0194\right)$. An ANCOVA on $\log _{10}$ - mean prey volume with $\log _{10}$-SVL as the covariate revealed no significant interactions between species*sex, 


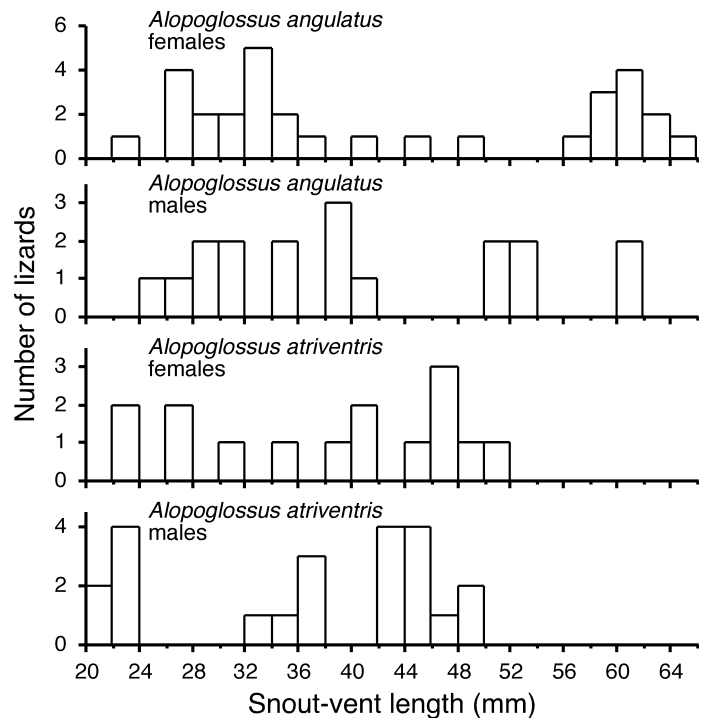

Figure 6 - Size distributions of male and female Alopoglossus angulatus and $A$. atriventris from western Amazonia.

sex* $\log _{10}-\mathrm{SVL}$, species* $\log _{10}-\mathrm{SVL}$, or species*sex* $\log _{10}-$ SVL $(\mathrm{P}$ values $>0.23$ ) so these were removed from the ANCOVA. The resulting ANCOVA revealed no effect of species or sex on $\log _{10}$ - mean prey volume $\left(F_{1,54}=0.83\right.$, $\mathrm{P}=0.365$ and $\left.\mathrm{F}_{1,54}=2.51, \mathrm{P}=0.119\right)$. An ANCOVA on $\log _{10}$ - number of prey per stomach with $\log _{10}-$ SVL as the covariate revealed no significant interactions between species*sex, sex* $\log _{10}$-SVL, species* $\log _{10}$-SVL, or species*sex* $\log _{10}-$ SVL $(\mathrm{P}$ values $>0.21$ ) so these were removed from the ANCOVA. The resulting ANCOVA revealed no effect of species or sex on $\log _{10}$ - number of prey $\left(\mathrm{F}_{1,54}=0.24, \mathrm{P}=\right.$ 0.625 and $\left.F_{1,54}=0.28, P=0.601\right)$. An ANCOVA on $\log _{10}$-total prey volume with $\log _{10}$-SVL as the covariate revealed no significant interactions between species*sex, sex* $\log _{10}$-SVL, species* $\log _{10}$-SVL, or species*sex* $\log _{10}$-SVL (P values $>0.13$ ) so these were removed from the ANCOVA. The resulting ANCOVA revealed no effect of species or sex on $\log _{10}$-total prey volume $\left(\mathrm{F}_{1,54}\right.$ $=1.35, \mathrm{P}=0.250$ and $\left.\mathrm{F}_{1,54}=1.98, \mathrm{P}=0.165\right)$.

\section{Discussion}

Both $A$. angulatus and $A$. atriventris occur in lowland tropical forest of the Amazon Basin (Ávila-Pires 1995). These small lizards are most often found in shaded or partially shaded leaf litter on the forest floor, but $A$. angulatus appears to have a slight tendency to be active near water whereas A. atriventris is usually active in leaf litter of terra-firme forest. Individuals of both species are active on sunny and cloudy days. Based largely on microhabitat temperature data $\left(\mathrm{T}_{\mathrm{ss}}\right.$ and $\left.\mathrm{T}_{\mathrm{a}}\right)$, these lizards occur in relatively cool $\left(23-29^{\circ} \mathrm{C}\right)$ microhabitats. Both species were active throughout the day, but peak activity in A. atriventris was earlier (late morning) than in $A$. angulatus. This difference may reflect hourly differences in environmental temperatures in terra firme forest (warm earlier) than in microhabitats closer to water (warm later). The possibility also exists that considerable activity occurs underneath or within leaf litter, and if so, then some activity might not have been observed.

Although A. angulatus and A. atriventris differ in SVL, they differ little in size-adjusted morphology. Heads of $A$. atriventris are relatively longer than those of $A$. angulatus, but this species difference may simply reflect effects of sexual dimorphism in head length of $A$. atriventris on the species comparison. Differences in morphology of male and female A. atriventris suggest males and females have responded differently to either natural selection or sexual selection. Larger heads in male lizards is common and cuts across many taxa globally. Increased head size of males is usually attributed to sexual selection in which males with relatively larger heads have a competitive advantage over males with relatively smaller heads in male-male interactions (e.g., Carothers 1984, Cooper and Vitt 1989, Anderson and Vitt 1990). Nevertheless, causes of sexual dimorphism are complex and can include both proximate (e.g., growth differences; resource use) and ultimate (sexual selection) causes 
Table 1 - Diets of 39 Alopoglossus angulatus and 19 A. atriventris from western Amazonia. No. is number of prey of a given category, \% No. is number of prey in a category divided by the total number of prey X 100 , Vol. is volume of prey of a given category, \% Vol. is volume of prey in a category divided by the total volume of prey $\mathrm{X} 100$, and Freq. is the number of lizards that ate a particular prey type.

\begin{tabular}{|c|c|c|c|c|c|c|c|c|c|c|}
\hline \multirow[t]{3}{*}{ Prey category } & \multicolumn{10}{|c|}{ Lizard species } \\
\hline & \multicolumn{5}{|c|}{ Alopoglossus angulatus } & \multicolumn{5}{|c|}{ Alopoglossus atriventris } \\
\hline & No. & $\%$ No. & Vol. & $\%$ Vol. & Freq. & No. & $\%$ No. & Vol. & \% Vol. & Freq. \\
\hline Roaches & 19 & 10.73 & 1708.67 & 53.58 & 16 & 7 & 10.14 & 887.52 & 57.95 & 6 \\
\hline $\begin{array}{l}\text { Grasshoppers/ } \\
\text { Crickets }\end{array}$ & 8 & 4.52 & 237.55 & 7.45 & 7 & 9 & 13.04 & 316.25 & 20.65 & 7 \\
\hline $\begin{array}{l}\text { Mantids and } \\
\text { Phasmids }\end{array}$ & - & - & - & - & - & 2 & 2.90 & 68.24 & 4.46 & 2 \\
\hline Homopterans & 10 & 5.65 & 70.85 & 2.22 & 8 & 1 & 1.45 & 5.61 & 0.37 & 1 \\
\hline Beetles & 4 & 2.26 & 12.76 & 0.40 & 4 & 1 & 1.45 & 1.12 & 0.07 & 1 \\
\hline Flies & 12 & 6.78 & 3.31 & 0.10 & 7 & 2 & 2.90 & 0.16 & 0.01 & 2 \\
\hline Hemipterans & 2 & 1.13 & 0.40 & 0.01 & 2 & - & - & - & - & - \\
\hline $\begin{array}{l}\text { Hymenopte- } \\
\text { rans (non-ant) }\end{array}$ & 1 & 0.56 & 0.08 & 0 & 1 & - & - & - & - & - \\
\hline Ants & 3 & 1.69 & 13.96 & 0.44 & 3 & - & - & - & - & - \\
\hline Lepidopterans & 1 & 0.56 & 0.19 & 0.01 & 1 & - & - & - & - & - \\
\hline Springtails & 24 & 13.56 & 5.00 & 0.16 & 12 & 14 & 20.29 & 0.71 & 0.05 & 4 \\
\hline Psocopterans & 1 & 0.56 & 0.04 & 0 & 1 & 1 & 1.45 & 0.41 & 0.03 & 1 \\
\hline $\begin{array}{l}\text { Larvae, eggs, } \\
\text { pupae }\end{array}$ & 5 & 2.82 & 42.50 & 1.33 & 4 & 3 & 4.35 & 8.39 & 0.55 & 2 \\
\hline Spiders & 54 & 30.51 & 997.57 & 31.28 & 25 & 21 & 30.43 & 240.61 & 15.71 & 11 \\
\hline Mites & 6 & 3.39 & 0.08 & 0 & 4 & 3 & 4.35 & 0.02 & 0 & 2 \\
\hline $\begin{array}{l}\text { Pseudo- } \\
\text { Scorpions }\end{array}$ & 1 & 0.56 & 0.43 & 0.01 & 1 & 2 & 2.90 & 1.31 & 0.09 & 1 \\
\hline Opiliones & 11 & 6.21 & 15.64 & 0.49 & 7 & - & - & - & - & - \\
\hline Isopods & 5 & 2.82 & 26.86 & 0.84 & 4 & 1 & 1.45 & 0.10 & 0.01 & 1 \\
\hline Millipedes & - & - & - & - & - & 1 & 1.45 & 0.49 & 0.03 & 1 \\
\hline Molluscs & 9 & 5.08 & 19.44 & 0.61 & 6 & 1 & 1.45 & 0.64 & 0.04 & 1 \\
\hline Plant material & 1 & 0.56 & 33.75 & 1.06 & 1 & - & - & - & - & - \\
\hline SUMS & 177 & 100.00 & 3189.08 & 100.00 & - & - & 100.00 & 1531.58 & 100.00 & - \\
\hline $\begin{array}{l}\text { Niche } \\
\text { breadths }\end{array}$ & & 6.99 & & 2.55 & & 69 & 5.93 & & 2.47 & \\
\hline
\end{tabular}


(Schoener 1967, Watkins 1996, Schwarzkopf 2005) and are difficult to sort out based on short-term sampling studies.

Diets and niche breadths of these lizards are similar. Roaches, spiders, grasshoppers/crickets, and springtails are predominant prey types numerically and volumetrically. Although all of these are likely common in Amazon rainforest leaf litter, diets of syntopic leaf litter lizards and frogs differ considerably from diets of these two gymnophthalmids. For example, the tiny leaflitter geckos Coleodactylus amazonicus, C. septentrionalis, Lepidoblepharis xanthostigma, and Pseudogonatodes guianensis feed primarily on springtails, homopterans, termites, insect larvae, and small spiders (Vitt et al. 2005). The most similar diets are found in some gymnophthalmids of the genus Cercosaura (formerly in Prionodactylus; Doan and Castoe 2005). For this discussion, we do not accept Doan's (2003) synonomy of C. oshaughnessyi and C. argulus (see Vitt et al. 2003b). Diets of C. oshaughnessyi and C. eigenmanni are dominated by grasshoppers/crickets, roaches, insect larvae, and spiders, a diet quite similar to that of the two species of Alopoglossus. We suggest that gymnophthalmids in general have diets that are somewhat more similar to each other than to lizards in more distant clades, likely reflecting dietary shifts away from other clades deep in their evolutionary history. These dietary shifts are likely associated with historic differences in morphology (including size) and behavior among clades. One of the historic dietary shifts identified by Vitt and Pianka (2005) was in the ancestor to gymnophthalmids and included data presented here. Reasons that varying numbers of species of gymnophthalmids can coexist in the same microhabitats (leaf litter) and feed on similar prey remain obscure, but the possibility exists that resources are rarely limiting in the structurally diverse mat of leaf litter on the floor of Neotropical forests.

Finally, it seems clear, as shown in studies of other small vertebrates of the Amazon rainforest, that the thick mat of leaf litter on the forest floor and the nearly continuous canopy are critical structural components of the habitat allowing these animals to persist. Leaf litter provides a structurally complex microhabitat filled with a diversity of small prey items, likely resulting in a superabundance of prey relative to lizard abundance (at least part of the time) and refuge from predators. The closed canopy creates a thermal environment allowing small lizard species that operate at relatively low temperatures to forage and move about with low risk of hyperthermy. Their small body size and thus low thermal inertia would place them at risk when clearings (natural or unnatural) allow sun access to the forest floor.

\section{Acknowledgments}

First, we thank all of the people who either helped coordinate our research in one or more areas or collaborated in data collection. They are: W. E. Magnusson, A. Lima, M. C. Araújo, J. P. Caldwell, V. Oliveira, M. Scheffer, and L. Coloma. Brazilian agencies contributing to logistics or research and collecting permits include SOS Amazônia and the Acre Union of Seringueiros in Rio Branco, the Instituto Nacional de Pesquisas da Amazonica (INPA), Conselho Nacional de Desenvolvimento Científico e Tecnológico (CNPq, Portaria MCT no. 170, de 28/09/94), the Instituto Brasileiro do Meio Ambiente e dos Recursos Naturais Renováveis (IBAMA, permit no. 073/94DIFAS), the Parque Estadual de Guajara-Mírim in Rondônia, and the Museu Paraense E. Goeldi in Belém. Brazilian research was conducted under a research convenio between the Sam Noble Oklahoma Museum of Natural History and the Museu Paraense E. Goeldi. We thank L. Coloma for coordinating our Amazonian research in Ecuador and the QCAZ in Quito for logistic support. The Estación Biológica de Cuyabeno in Ecuador was made available by the Universidad Católica and permits were issued by Ministry of Agriculture and Livestock of the Republic of Ecuador. All animals were treated in 
accordance with federal, state, and university regulations (Animal Care Assurance 73-R-100, approved 8 November 1994). We thank American and Varig Airlines for allowing excess baggage. This material is based partially upon work supported by the National Science Foundation under Grant Numbers DEB9200779 and DEB-9505518 to LJV and J. P. Caldwell. Any opinions, findings, and conclusions or recommendations expressed in this material are those of the author(s) and do not necessarily reflect the views of the National Science Foundation.

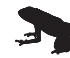

\section{References}

Anderson, R. A. and L. J. Vitt. 1990. Sexual selection versus alternative causes of sexual dimorphism in teiid lizards. Oecologia (Berlin) 84: 145-157.

Anonymous. 1987. Guidelines for the use of live amphibians and reptiles in field research. Publication of the American Society of Ichthyologists and Herpetologists, the Herpetologists' League, and the Society for the Study of Amphibians and Reptiles. 14 pp.

Ávila-Pires, T. C. S. 1995. Lizards of Brazilian Amazonia (Reptilia: Squamata). Zoologische Verhandelingen 299: 1-706.

Beebe, W. 1945. Field notes on the lizards of Kartabo, British Guiana, and Caripito, Venezuela. Part 3. Teiidae, Amphisbaenidae and Scincidae. Zoologica 30: 7-32.

Carothers, J. H. 1984. Sexual selection and sexual dimorphism in some herbivorous lizards. American Naturalist 124: 244-254.

Castoe, T. A., T. A. Doan and C. L. Parkinson. 2004. Data partitions and complex models in Bayesian Analysis: the phylogeny of gymnophthalmid lizards. Systematic Biology 53: 448-469.

Colli, G. R., R. P. Bastos and A. F. B. Araujo. 2002. The character and dynamics of the Cerrado herpetofauna. Pp 223-241 in P. S. Oliveira and R. J. Marquis (eds.), The Cerrados of Brazil: Ecology and Natural History of a Neotropical Savanna. New York. Columbia University Press.

Cooper, W. E., JR. and L. J. Vitt. 1989. Sexual dimorphism of head and body size in the iguanid lizard Sceloporus undulatus: paradoxical results. American Naturalist 133: 729-735.

Doan, T. M. 2003. A new phylogenetic classification for the gymnophthalmid genera Cercosaura, Pantadoctylus and Prionodactylus (Reptilia: Squamata). Zoological Journal of the Linnean Society 137: 101115.

Doan, T. A. and T. A. Castoe. 2005. Phylogenetic taxonomy of the Cercosaurini (Squamata: Gymnophthalmidae), with new genera for species of Neusticurus and Proctoporus. Zoological Journal of the Linnean Society 143: 405-416.

Duellman, W. E. 1978. The biology of an equatorial herpetofauna in Amazonian Ecuador. Miscellaneous Publications of the Museum of Natural History of the University of Kansas 65: 1-352.

Duellman, W. E. 1987. Lizards in an Amazonian rain forest community: resource utilization and abundance. National Geographic Society Research 3: 489-500.

Hoogmoed, M. S. 1973. Notes on the herpetofauna of Surinam. IV. The lizards and amphisbaenians of Surinam. Biogeographica 4: 1-419.

Huey, R. B., Pianka, E. R. and Vitt, L. J. 2001. How often do lizards 'run on empty'? Ecology 82: 1-7.

Magnusson, W. E., A. P. Lima, W. A. Silva, and M. C. Araújo. 2003. Use of geometric forms to estimate volume of invertebrates in ecological studies of dietary overlap. Copeia 2003: 13-19.

Moraes, R. C. 1993. Ecologia das especies de Calyptommatus (Sauria, Gymnophthalmidae) e partilha de recursos com outros dois microteiídeos. Unpublished M.Sc. Dissertation. Universidade de São Paulo, Brazil.

Pellegrino, K. C. M., M. T. Rodrigues, Y. YonenagaYassuda, and J. W. Sites Jr. 2001. A molecular perspective on the evolution of South American microteiid lizards (Squamata, Gymnophthalmidae), and a new classification for the family. Biological Journal of the Linnean Society 74: 317-340.

Pianka, E. R. 1973. The structure of lizard communities. Annual Review of Ecology and Systematics 4: 53-74.

Pianka, E. R. 1986. Ecology and natural history of desert lizards. Analyses of the ecological niche and community structure. Princeton. Princeton University Press. 222 pp.

Pianka, E. R. and L. J. Vitt. 2003. Lizards: windows to the evolution of diversity. Berkeley. The University of California Press. 348 pp.

Pough, F. H., R. M. Andrews, J. E. Cadle, M. L. Crump, A. H. Savitzky, and K. D. Wells. 1998. Herpetology. Upper Sadler River. Prentice Hall. 577 pp.

Rodrigues, M. T. 1996. Lizards, snakes, and amphisbaenians from the quaternary sand dunes of the middle Rio São Francisco, Bahia, Brazil. Journal of Herpetology 30: 513-523. 
Rodrigues, M. T., E. M. X. Freire, K. C. M. Pellegrino, and J. W. Sites Jr. 2005. Phylogenetic relationships of a new genus and species of microteiid lizard from the Atlantic Forest of north-eastern Brazil (Squamata, Gymnophthalmidae). Zoological Journal of the Linnean Society 144: 543-557.

Schoener, T. W. 1967. The ecological significance of sexual dimorphism in size in the lizard Anolis conspersus. Science 155: 474-476.

Schwarzkopf, L. 2005. Sexual dimorphism in body shape without sexual dimorphism in body size in water skinks (Eulamprus quoyii). Herpetologica 61: 116123.

Simpson, E. H. 1949. Measurement of diversity. Nature 163: 688 .

Vitt, L. J. 1995. The ecology of tropical lizards in the Caatinga of northeast Brazil. Occasional Papers of the Oklahoma Museum of Natural History 1: 1-29.

Vitt, L. J. and T. C. S. Ávila-Pires. 1998. Ecology of two sympatric species of Neusticurus (Sauria: Gymnophthalmidae) in the western Amazon of Brazil. Copeia 1998: 570-582.

Vitt, L. J. and E. R. Pianka. 2005. Deep history impacts present-day ecology and biodiversity. Proceedings of the National Academy of Sciences 102: 7877-7881.

Vitt, L. J. and S. de la Torre. 1996. Guia para la Investigacion de las Lagartijas de Cuyabeno: A research guide to the lizards of Cuyabeno. Quito. Museo de Zoologia (QCAZ), Centro de Biodiversidad y Ambiente, Pontificia Universidad Catolica del Ecuador, Monograph \#1.

Vitt, L. J., E. R. Pianka, J. W. E. Cooper and K. Schwenk. 2003a. History and the global ecology of squamate reptiles. American Naturalist 162: 44-60.

Vitt, L. J., S. S. Sartorius, T. C. S. Ávila-Pires, and M. C. Espósito. 1998a. Use of time, space, and food by the gymnophthalmid lizard Prionodactylus eigenmanni from the western Amazon of Brazil. Canadian Journal of Zoology 76: 1681-1688.

Vitt, L. J., P. A. Zani, T. C. S. Ávila-Pires, and M. C. Espósito. 1998b. Geographical ecology of the gymnophthalmid lizard Neusticurus ecpleopus in the Amazon rain forest. Canadian Journal of Zoology 76: 1671-1680.

Vitt, L. J., T. C. S. Ávila-Pires, P. A. Zani, M. C. Espósito, and S. S. Sartorius. 2003b. Life at the Interface: Ecology of Prionodactylus oshaughnessyi in the western Amazon with comparisons to P. argulus and $P$. eigenmanni. Canadian Journal of Zoology 81: 302-312.

Vitt, L. J., S. S. Sartorius, T. C. S. Ávila-Pires, P. A. Zani, and M. C. Espósito. 2005. Small in a big world: ecology of leaf-litter geckos in New World tropical forests. Herpetological Monographs 19: 137-152.

Watkins, G. W. 1996. Proximate causes of sexual size dimorphism in the iguanian lizard Microlophus occipitalis. Ecology 77: 1473-1482.

Zug, G. R., L. J. Vitt and J. P. Caldwell. 2001. Herpetology: an introductory biology of amphibians and reptiles. San Diego. Academic Press. 630 pp. 